\title{
Transfusion-free treatment of Jehovah's Witnesses: respecting the autonomous patient's motives
}

David Malyon Chairman, Hospital Liaison Committee for fehovah's Witnesses, Luton

\begin{abstract}
What makes fehovah's Witnesses tick? What motivates practitioners of medicine? How is benevolent human behaviour to be interpreted? The explanation that fear of censure, mind-control techniques or enlightened self-interest are the real motivators of human conduct is questioned. Those who believe that man was created in "God's image", hold that humanity has the potential to rise above selfishly driven attitudes and actions, and reflect the qualities of love, kindness and justice that separate us from the beasts. A comparison of general medical ethics and disciplines, and those of the fehovah's Witness community, is made in this context. The easy charge that frequent deaths result from refusal of blood transfusions is examined. The central source of antipathy towards fehovah's Witnesses, namely the alleged imposition of extreme and even harmful refusal of blood therapy on our children is addressed. Of course, "... few dilemmas are likely to be resolved wisely or satisfactorily by a blinkered adherence to abstract principles alone. Solutions to most cases will be dictated by a combination of factors. ${ }^{1}$ The support of medical ethics by fehovah's Witnesses, and their willingness to share in reasoned and ethical debate, while at the same time holding firm to their religious and conscientious principles are emphasised.
\end{abstract}

(Fournal of Medical Ethics 1998;24:376-381)

Keywords: Disciplinary measures; blood alternatives; dissidents; moral motivation; Jehovah's Witnesses

\section{Introduction}

In recent editions the journal has included two, in my view erroneous and ill-considered attacks on my faith and that of my fellow Jehovah's Witnesses. ${ }^{2-3}$ Particularly offensive is the ascription of ulterior motives, attitudes and practices to our members. In my first responding paper ${ }^{4}$ I considered the rights of Jehovah's Witnesses. In this second paper responding to Dr Muramoto, I give an account of our faith and of our attitudes and motivation with regard to blood transfusions.
Religious, medical and personal motives Like the rest of us, doctors must answer to their consciences. " . . to thine own self be true ...". However, again like the rest of us doctors are als $\dot{\omega}$ governed by the criminal and civil law. They muse satisfy their patients of their performance ancs ethical integrity. In addition, they submit to the discipline of examination by their peers in professional body. In England this is the Genera $\$$ Medical Council (GMC) and disregard of such legal and professional constraints could result in eventual suspension or even revocation of the doctor's licence. Without such discipline sociotyo would lose confidence in the skill of doctors, thif patients would seek other practitioners, their peers would start to ignore them, and eventually the too would lose confidence in themselves and theio own ability. In a recent sad case an eminent hear $\$$ surgeon resigned in similar circumstances t $\vec{\sigma}$ these. ${ }^{6}$

However, do these constraints form the under? lying ethical "bedrock" for the practice of medicine? Do doctors "behave themselves" only because of fear of censure? Dawkins in the The Selfish Gene argues that "genetic" self-interest is the "modus operandi" for all of the natural world" including the human race. ${ }^{7} \mathrm{He}$ affirms that "we्3 are survival machines-robotic vehicles, blindlyo programmed to preserve the selfish molecules know as genes. This is a truth which still fills me with astonishment". (I share his astonishment that all that is pure and beautiful can so easily be diso missed!) This is an old debate! "Love seeketh not itself to please, nor for itself hath any care, but fot another gives its ease, and builds a heaven in hell' despair ...". 8

The Christian believes that "love" is and mus है be the principal motivation for upright conduct. $A^{(4)}$ desire to do good to their patients, to society, and to uphold the standards of their own colleagues must surely drive the majority of members of the medical profession rather than the cash benefits! $\mathbb{R}$ leading consultant surgeon confirms: "Many of my colleagues and myself and the nursing staff, 
over many years have contributed well above what we are paid for in terms of time, hours, effort and expertise. The reason? We believe and love the NHS as a concept". ${ }^{9}$ Is a man faithful to his wife because she is a good cook, a good conversationalist, or even a good lover? Although such assets may have originally attracted him to her the great description of love in The Bible is recognised by many as the driving force in the closest, and in other, personal relationships. "Love is patient and kind; it is not jealous or conceited or proud; love is not ill-mannered or selfish or irritable; love does not keep a record of wrongs; love is not happy with evil, but is happy with the truth. Love never gives up, and its faith, hope and patience never fail ...". ${ }^{10}$ The deficiency of law in keeping mankind in order was revealed outstandingly by the teachings of Jesus Christ in the Sermon on the Mount. "Do not kill" becomes "do not be angry", "do not commit adultery" becomes "do not think about it", "love your friends" becomes "love your enemies". Jesus realised that the heart, or motivation, must be pure if the actions are to be likewise. ${ }^{11}$ Parliament has long ago given up the Victorian thought of moral education by law. As usual The Bible is so apt: "We know that the law is good if it is used as it should be used. It must be remembered, of course, that laws are made, not for good people, but for law-breakers and criminals, for the godless and sinful ... the purpose of this order is to arouse the love that comes from a pure heart, a clear conscience and a genuine faith . . .". ${ }^{12}$ Mankind, the "flawed genius", is rightly subject to law, however, and humility causes many of us to admit that we have slowed our speeding vehicles at the sight of a revolving blue light, and that the reduction of speed appears to last a little longer when the blue light is replaced with a flashing camera!

The Watchtower states that “Jehovah's Witnesses are motivated by love for God, and their fellow humans. True they are closely knit together by the bond of Christlike love as a worldwide association of brothers. But as free moral agents, each one has personally decided to live by Bible standards. These are decisions that fall within the framework of a way of life freely chosen [my italics] by potential Witnesses before they ever take the step of Christian [baptism]". ${ }^{13}$

Doctors may see some similarity in their personal commitment to the Hippocratic Oath or the International Code of Medical Ethics. ${ }^{14}$ The Witnesses regard themselves as performing a public service of education and of encouragement to adopt Christ's principles, which they feel are so badly needed in the world today. We too must answer to our own consciences, we must keep the law, and must show respect for all whom we seek to contact. Our ability to do our work effectively, depends to a large extent upon our reputation in the community as honest and respectable people, whether our religious principles are accepted or not. To believe that the procedure of "examination by peers" which the Witness community uses to uphold good conduct, and which can ultimately lead to "excommunication" is the prime or even the only motivation for our religious activities, is to impugn our motives, and by implication the motives of other professionals who subscribe to disciplinary action. The parallel implied above can be developed further. It is of interest that a large majority of doctors who are struck off eventually return to the medical register, and that the GMC disciplinary committee seeks to tailor the "punishment to the crime", taking into consideration such factors as intent, attitude and prior counselling. Outsiders not in possession of the full facts frequently criticise their sincerely reached decisions, and even the procedure itself (a recent case in point being comments from the British Minister of Health)! ${ }^{6}$

Similarly the disciplinary measures of Jehovah's Witnesses carefully analyse the attitude of the offender. Never is anyone disfellowshipped if he or she displays a repentant attitude, and happily a large number of those thus censured by this rarely used procedure, are eventually restored to our congregations. Of course, Jesus' story of the prodigal son reveals the wisdom of excommunication even though in this case it was voluntary separation on the son's part. The prodigal returned only after he had realised what he had lost, and the return to his own senses and to his father's love was indeed a warm one.

\section{Risk/benefits in refusing blood transfusions}

Muramoto's central assumption is that the lives of "many" Jehovah's Witnesses are lost because of their refusal to accept blood transfusions. Where are his statistics? Kitchens ${ }^{15}$ states that " . . . blood is usually administered by physicians with the nearly unchallenged view that failure to transfuse would have dire consequences. Evidence supporting that view is very difficult to obtain". Death certificates seldom mention negative reasons. "Doctor arrived too late", "no cardiac unit available", "penicillin not yet discovered", are not acceptable as the primary reason for death. Inquests usually bring in a verdict of natural causes or misadventure even in cases where extreme loss of blood was obviously involved. Why is Muramoto so certain that his assumption is 
Table 1 fehovah's Witnesses undergoing major surgery without blood transfusions

\begin{tabular}{lll}
\hline Procedures & $\begin{array}{l}\text { No of } \\
\text { operations }\end{array}$ & $\begin{array}{l}\text { Deaths associated } \\
\text { with anaemia }\end{array}$ \\
\hline Cardiovascular & 542 & 15 \\
Cardiovascular & 36 & 3 \\
Total hip replacement & 107 & 0 \\
Total hip replacement & 100 & 0 \\
Obstetrics/gynaecology & 165 & 0 \\
Obstetrics/gynaecology & 96 & 0 \\
General surgery & 27 & 0 \\
Paediatric cancer & 9 & 0 \\
CABG & 46 & 0 \\
CABG & 13 & 0 \\
Renal transplantation & 11 & 0 \\
Paediatric cardiovascular & 30 & 0 \\
Cardiovascular & 13 & 0 \\
General surgery & 78 & 1 \\
Paediatric cardiovascular & 112 & 1 \\
Spinal fusion & 19 & 0 \\
Total & 1404 & $20(1.4 \%)$ \\
\hline
\end{tabular}

American fournal of Medicine volume 94:119 Editorial

correct? The American journal article referred to above considered 16 studies involving 1404 operations and reported that the authors ${ }^{16}$ " ... implicated a lack of blood as the primary cause of death in 8 patients $(0.6 \%)$ and contributing to death in another 12 patients, yielding a total of 20 deaths $(1.4 \%)$.... Other complications were not increased in Jehovah's Witness patients compared with other patients ... . Less clear is how much morbidity and mortality are avoided by this practice [refusal of blood], but they probably exceed the risk of being transfused . . .. Rather than reflexively administering blood, a physician must consider the risk-benefit ratio as they would for any [my italics] drug or procedure". See table 1. Is it surprising that the editorial was entitled Are transfusions overrated? The Lancet further observed: "Because of the risks of transmitting disease and compromising immune defences, transfusion of homologous blood should be avoided when possible, not only in adults but also in children". ${ }^{17}$ Nielsen has 139 references to established medical papers as “. . . evidence suggesting that perioperative allogenic blood transfusion increases the risk of infectious complications after major surgery and of cancer recurrence after curative operations . . also contributing to immuno-suppression". ${ }^{18}$ Are these authoritative studies part of the "exaggerated negative campaign against blood transfusion" mentioned by Muramoto? Why are the international drug companies involved in a systematic search for recombinant blood alternatives?

When it comes to dying or living Judge Lady Butler Sloss in the Court of Appeal stated “ . . . Jehovah's Witnesses accept and take advantage of the same medical treatment as those who do not subscribe to their beliefs and are as anxious as anyone else to recover from any illness from which they may suffer. There is no question of a right to die . . . ${ }^{19}$ Her colleague Lord Donaldson: concurred: "This appeal is not in truth about the right to die, [rather] it is about the right to choose how to live...". To summarise, if the Court of Appeal in the recent caesarean case ${ }^{20}$ can allow an appeal which involved a pregnant woman witha "... an unusual, even apparently bizarre and irra tional thinking process, and contrary to the views of the overwhelming majority of the community at large ..." then how much more recognition musw be given to an adult Jehovah's Witness whose refusal of one single medical procedure is basedb upon religious, ethical, and proven medical opin ion. The "community at large" certainly has had æo massive sea change of opinion against the therapeutic use of blood.

\section{Children and parental/medical responsibilities}

Children are not "owned" by their parents. How ever, parents should feel a responsibility towards their children. They have the privilege of teachigge them their own moral principles in such a way that the children will feel free to develop their on value systems from the background of the parents. Wise parents allow freedom in such development. Medical Ethics Today ${ }^{21}$ says: "Recen studies appear to show also that when entrusted with responsibilities children and young people를 often respond well, but when perceived by others as immature, respond accordingly. Such studies have contributed to the increasing empowerment of children and young people". Indeed! How many of us can remember responding to the exhortation to "grow up" with a surly determination not to! Jehovah's Witnesses accept such responsibilities towards their children with love and consideration. They cannot and should not beo expected to consent to a medical treatment which they feel is against God's wishes and may beㅡ. medically questionable. Again, new overtures by the hospital liaison committee network enable the development of trust between a child's doctor and the parents. The doctor acknowledges the parents $\tilde{\omega}$ refusal of blood, yet agrees to honour their refusap to the point in his opinion, of not allowing theo child to die or suffer injury. Jehovah's WitnessesD and everyone else are bound by the present? understanding in law that doctors must act in the best interest of the child as an overriding factor Savulescu $e t a l^{2}$ raised questions about the "bes? interests" doctrine in a case involving the donation of bone marrow by a six-year-old sister for the benefit of her nine-year-old sibling. They argued 
that it might have been in the "best interests" of the nine-year-old, but questioned whether it was in the "best interests" of the six-year-old, and how could the consent of the parents for such a procedure be unquestioned? A more recent case involved the refusal of a mother to accept a liver transplant for her severely damaged child, even though this refusal would inevitably lead to the child's death. Surely such cases demonstrate that these medical dilemmas should be handled with sensitivity on a case-by-case basis, rather than by a blanket doctrinal approach.

The hospital liaison committees are heard when such cases arise, and Witness parents receive support and advice, but also the medical professionals are made aware of the ethical issues involved. Frequently such activity results in a satisfactory outcome for everyone involved, with the health of the child being paramount. Of course, differing views about mature minors, second opinions, and very avant garde treatments may confuse such basic principles, but in fact few of our children are being transfused. Cooperative doctors, medical advances and the proactive hospital liaison committee network have obviated much of the controversy surrounding the treatment of Witness children. Actually, a "child" cannot be one of Jehovah's Witnesses. We practise adult or mentally competent baptism following the pattern of Jesus Christ. Of course, we are glad if our children espouse our beliefs, but as I reject Muramoto's claim of adult control, so I reject the thought that Witness parents "indoctrinate" their children. My own daughter, in company with the children of so many, could not be told what to do, certainly from the age of six months onwards, yet from the time she was a teenager has enthusiastically adopted the faith of her parents. Our two granddaughters appear to have inherited their mother's lack of malleability.

\section{Internet ethics and anonymity}

Professor Muramoto questions the motives of the Watchtower Society and also of the membership at large. At least he has the honesty to declare his motives on his public website on the Internet, where he openly admits to religious differences with his own Jehovah's Witness wife. To be utterly forthright, I believe that such disclosure of interest should have been made on publication of his first article; none the less he has the merit of accepting responsibility. How can similar respect be accorded to anonymous dissidents, some of whom still claim to be members of our fellowship? Usual police advice about the receipt of anonymous letters is to ignore them. Isn't that advice still good when it comes to anonymous offerings on the
Internet? With so much accredited religious, legal and medical information on my faith readily available in over 250 languages why should such wild and unfounded accusations as appear on the Internet be considered? Maybe Thurber's advice is apt: "Get it right or leave it alone, the conclusion you jump to, may be your own"! ${ }^{23}$

\section{Blood semantics}

Muramoto makes much of the argument that transfusions are not "eating". My original article explained that the blood "laws" in The Bible are based upon the reverence for life and its association with blood. However, of interest is The Times law report ${ }^{24}$ entitled Consuming through injection. It discusses the case in which a person was charged with driving with an excess of alcohol present in his body. The alcohol had been "consumed" when a doctor injected the defendant with Kenalog containing a $1.5 \%$ benzyl alcohol. The law report defined that "consuming' in its usual context did not embrace sniffing, or absorbing by way of injection or some patch attached to the body, but was capable of a variety of meanings depending on the context. The court was not entitled to restrict the meaning of consuming to the act of drinking, and to no other mode of introduction or injection ...."

I am not medically qualified to discuss $\mathrm{Mu}-$ ramoto's convoluted reasoning about blood being a cellular organ transplant further than to highlight the danger of pedantically limiting word meanings. All law, as I have previously stated, must be kept in the spirit as much as in the letter!

\section{Religious liberty in Europe}

Professor Massimo Introvigne's ${ }^{25}$ thoughtful review suggested that a rise in intolerance against religious minorities is developing. Openness in medicine, government, religion and almost everything else is becoming the criterion. Jehovah's Witnesses welcome honest examination. Their meetings, literature, and branch and central offices are open to all sincere investigators. The Witnesses subscribe to the view expressed above-if you have nothing to hide why should you need to be secretive? However, Professor Introvigne believes that truth is distorted by listening to the claims of ex-members of "sects" in isolation. Actually his study only mentions Jehovah's Witnesses once, in passing. His article is not about Jehovah's Witnesses. He does, however, believe, in company with the vast majority, that: "Good ethics start with good facts ...", ${ }^{25}$ and is concerned that frequently only one side (and the negative side at that) is heard. One small point 
gives the flavour of his paper: "Words are not neutral. Words such as 'cults' are easily used as tools of hate and discrimination, and should be avoided ... the most neutral term is 'religious minorities"'. Respect for another point of view is also part of human rationality and conscience. The Times $^{26}$ has a profoundly moving story "of a couple who found a stranger, a boy, dying of knife wounds as they walked home. They held him in their arms and spoke loving words, and when he got home the man could not even bear to throw away the water that rinsed his bloodstained shirt. $\mathrm{He}$ poured it onto a growing rosebush as an instinctive gesture of respect for the boy's dying body . ..." Surely an illustration of an "intuitive moral sense" associated with life, death and blood. Respect for life, blood, conscience, and liberty are the bedrock of civilisation, let alone the faith of Jehovah's Witnesses.

\section{Discussion of Muramoto's hypothetical religion and appendix}

I believe that my two articles have demonstrated that Muramoto's suggestions are unethically based, legally erroneous, medically dangerous, morally questionable and theologically superficial. The temerity of his appendix, a protocol which he suggests doctors adopt in treating all nonemergency surgery Witness patients is nothing short of an abusive transformation of the medical role of succour and care into that of "devil's advocate" and "trickster". For example in Appendix 3 his argument is merely a cleverly worded duplication of the view that "life must be saved at all costs". Blood is sacred because it symbolises life, LIFE is sacred because - Christians hold - it is a gift from God, and that life must be lived (or died) in the consciousness of this reality. Jehovah's Witnesses respect the gift of life by adopting healthy lifestyles: we avoid nicotine, recreational drugs, alcohol abuse, sexual promiscuity AND "abstain" from blood. Are doctors interested in engaging in, or qualified to engage in, theological argument with patients already anxious and possibly vulnerable because of the need for medical treatment? Muramoto says: "Some may argue that these questions make a value judgment of religious beliefs under the guise of medical discussion ... that posing those questions is manipulative towards the patient's religious faith ..." ${ }^{3}$ Exactly right! I do believe Muramoto's appendix is an affront to my faith, and an attempt to coerce our members with complicated philosophical inquisition. We welcome sincere questions. But no one would welcome their deeply held convictions being attacked under the cloak of sincerity.

\section{Availability of alternatives}

Thomas, ${ }^{27}$ concluding a major article entitled The worldwide need for education in nonblood: management in obstetrics and gynaecology, noted that: "It should be clear from the foregoing tha? many viable alternatives to the use of blood trans $\frac{\bar{\sigma}}{\bar{c}}$. fusions do exist and are available to all practising obstetricians and gynaecologists. It is not the lacko of these facilities but perhaps a lack of knowledge about them, which may inhibit many practitioners 5 from their useful application ...". Probably theslow, progressive, careful advancement in medica $\vec{\rho}$ practice is generally beneficial for patients Waldenstrom ${ }^{28}$ has the salutary story of thep inscription on a tombstone reading: "I felt welli but wanted to feel better-therefore I am here! The careful adjustment of therapy in order to obtain slow but steady improvement is often? superior to the dramatic results that seem more? striking ...". This was with reference to the treat ment specifically of the leukaemias. However ignorance of now widely recognised and fre $\frac{\mathbb{D}}{3}$ quently employed techniques to avoid totally the्ष use of transfusions should no longer be the cause of tension between the medical community and Jehovah's Witnesses. Medical literature is com $-\infty$ stantly presenting articles on blood conservatiền benefits, the use of intra-operative blood salvage, haemodilution advances, plasma expanders ando ultrasonic tools, let alone advances with drugo therapies, including the use of erythropoietin, aprotinin, etc. The American fournal of Surgery contains a useful 80-page review of the "state of the art" in bloodless medicine. Hospitals with protocols for treating adult patients without blood. are legion throughout the world, with over $120 \overline{3}$ such centres in the USA alone. Neonatal special- $\frac{}{\circ}$ ists are developing new micro blood-sampling techniques, including the use of an infrared-scano optical probe. The Witnesses hospital liaison? committee network has information freely avail-o able in a short fact sheet which itemises $105^{9}$ medical references to bloodless, medical and sur-o gical strategies and I would be happy to supply such on request or reply to any comments. ${ }^{30}$ Such ${ }^{\circ}$ ongoing progress suggests to some that the 0 general use of transfusions will eventually become obsolete.

\section{Conclusion}

The charges against our views in a medicalo context are clearly out of date! Our faithful adherence to Biblical tenets has resulted in the develop $\frac{\mathrm{O}}{\mathrm{D}}$ ment of new surgical and medical techniques too obviate the use of blood therapy, which are in the very forefront of medical developments. The 
atmosphere between members of our faith and the medical profession as a whole is becoming increasingly relaxed and even friendly. Even when misunderstandings have arisen our members have assumed that doctors and surgeons have been well-intentioned. History is full of examples of hatred and conflict following behind suspicion of pure motives. Surely our movement has the right to expect that its members' actions as well as their motives be treated with optimism and respect.

\section{Response to author's note}

I was asked reply to Dr Muramoto's articles by the journal's editor. I felt it wrong to ascribe bad motives to Dr Muramoto. However, his late author's note ${ }^{3}$ does, I believe, reveal the extent of his mischief-making. After years of persecution, dating back to the second world war, an amicable agreement was brokered between the government of Bulgaria and Jehovah's Witnesses by the European Commission for Human Rights. Alain Garay, Avocat a la cour, Paris was instructed by Jehovah's Witnesses to be part of the negotiating team and he confirms that "it was accepted by all sides that the agreement reflected normal practice within the Jehovah's Witness religion around the world" (personal communication from A Garay). As I have stated, we do not monitor the medical choices of our members, and even if we were to learn one had accepted a blood transfusion our ministers would still offer pastoral care. The Charter of the Christian Association of Jehovah's Witnesses accepted by the Bulgarian government accords with the unchanged and long established beliefs of Jehovah's Witnesses internationally: "The Denomination of Jehovah's Witnesses of Bulgaria may not exercise any control over the free will of believers but allows them to exercise their conscience consistent with godly Bible principles. Nor does the Denomination arbitrarily apply sanctions in connection with the medical care that Jehovah's Witnesses conscientiously seek for themselves and their children. The Denomination adheres to the loving and righteous principles of God's Word in this aspect of Christian life." Dated July 15 th 1998 , confirmed October 7 th 1998 . Six million Jehovah's Witnesses are not confused!

I feel like echoing the words of Anne Frank ${ }^{31}$. "It's difficult in times like these: ideals, dreams and cherished hopes rise within us, only to be crushed by grim reality. It's a wonder I haven't abandoned all my ideals, they seem so absurd and impractical. Yet I cling to them because I still believe in spite of everything, that people are truly good at heart".
Acknowledgement

My thanks to my patient "Secretary" Fran Skinner

David Malyon is Chairman of the Fehovah's Witnesses Liaison Committee, Luton, Bedfordshire.

\section{References}

1 British Medical Association. Medical ethics today. London: British Medical Association 1993:318.

2 Muramoto O. Bioethics of the refusal of blood by Jehovah's Witnesses: part 1 . Should bioethical deliberation consider dissidents' views? Fournal of Medical Ethics. 1998;24:223-30.

3 Muramoto O. Bioethics of the refusal of blood by Jehovah's Witnesses: part 2. A novel approach based on rational non-interventional paternalism. Fournal of Medical Ethics. 1998;24:295-301.

4 Malyon D. Transfusion-free treatment of Jehovah's Witnesses-respecting the autonomous patient's rights. Fournal of Medical Ethics 1998;24:302-307.

5 Shakespeare W. Hamlet. Act 1 Scene 3.

6 Treasure T. Lessons from the Bristol case. British Medical fournal 1998; 316:1085-6.

7 Ridley M. Origins of virtue. Harmondsworth: Penguin, 1996:19.

8 Blake W. Songs of innocence. Oxford: Oxford University Press, 1789.

9 Ritchie A. Good will keeps the NHS going. Sunday Times. 1998 Jul 5:5.10.

10 The Bible. 1 Corinthians 13:4-7.

11 The Bible. Matthew 6:22.

12 The Bible. 1 Timothy $1: 8,9,5$.

13 Anonymous. Living up to Christian dedication in freedom. The Watchtower 1998 Mar 15: 20.

14 See reference $1: 326,327$.

15 Kitchens CD. Are transfusions overrated?[editorial]. American Fournal of Medicine 1993; 94:117-19.

16 See reference 15 and table 1.

17 van Iterson $\mathrm{N}$ et al. Systemic haemodynamic and oxygenation during haemodilution in children. Lancet 1995;346:1127.

18 Nielsen HJ. Detrimental effects of perioperative blood transfusion. British Fournal of Surgery 1995:82:582-7.

19 In Re T (Adult: refusal of treatment) 1993 Fam 95 CA.

20 St George's NHS Trust v S; REG v Collins, Ex Parte S 19983 All ER 673.

21 See reference 1:75.

22 Savulescu J et al. Altruism by proxy: volunteering children for bone marrow donation - substantial harm but substantial benefit. British Medical fournal 1996;312:242.

23 Thurber J. Vintage Thurber. London: Hamish Hamilton, 1963: 401.

24 The Times Law Reports. Consuming through injection. 1996 Feb 15. See also Director of Public Prosecutions v Johnson 19951 WLR 728 DC.

25 Introvigne M. Religious liberty in Europe. Turin, Italy: Centre for Studies on New Religions, 1997:4.

26 Purvis L. This was a baby too far. The Times 1998 Jun 30: 20.

27 Thomas JM. The worldwide need for education in nonblood management in obstetrics and gynaecology. Fournal of the Society of Obstetricians and Gynaecologists of Canada 1994;Mar: 1486.

28 Waldenstrom J. To treat or not to treat, this is the real question. Medical Oncology $\mathcal{E}$ Tumour Pharmacology 1986:3:3-4.

29 American fournal of Surgery 1995:170:6A. Consensus conference: Blood management, surgical practice guidelines. Guest editor, Spence RK. (The whole issue is devoted to the coverage of this conference.)

30 Hospital Liaison Committees for Jehovah's Witnesses. Address and contact details for correspondence, comment and request for literature: c/o David Malyon, 3 Rose Vale, Hoddesdon, Herts. EN11 8NR. Tel: 01992 443104. Fax: 01992470820.

31 Frank A. The diary of a young girl. Harmondsworth: Penguin, 1997:330. 